\title{
The STAR-TREK Borg As an All-American Captivity Narrative
}

\begin{abstract}
The Borg are half-human/half-robot beings that have appeared in various film and television versions of Star Trek since first created in the 1980s for the television series Star Trek: The Next Generation. Mindless automatons whose only purpose is to turn as many other humanoids into Borgs as possible, the Borg may superficially appear to be a metaphor for world Communism as it was metaphorically represented in Westerns and science fiction from the 1950s onward. However, the Cold War has long since ended and the Borg are as popular as ever in the Star-Trek franchise. This is because they are a modern manifestation of the 400-year-old American captivity narrative - the first distinct literary genre created in the New World. Rather than a metaphoric iteration of the Communist threat, the Borg instead represent the age-old American paranoia of being held in thrall by an Other who would drag Americans where they do not wish to be dragged.
\end{abstract}

\section{Key words}

American literature; the captivity narrative; science fiction film; the cyborg

In estimating the value of the Borg to the five-decade-old Star Trek franchise, Nicholas Mirzoeff states that the half-human-half-machine collective automatons "injected new life into a series that had long been marked by nostalgia for the original 1960s television program and its ageing stars" (1999: 214). The Borg are not exactly an alien race like the Klingons, who were first enemies, then friends; or the Romulans, a nefarious lot in every Trek iteration; or the Vulcans, a race of noble stoics who are the indirect reason for Earth's status as a near-utopia in the 24th century. Instead, the Star-Trek Borg are always whomever is unfortunate enough to be assimilated and forced into a life of near-mindless collective 
existence, fated to serve the needs of the greater society with no individuality or self-interest to be manifest, and with no ultimate goal other than to turn every non-Borg humanoid encountered into a member of the collective. Resistance, after all, is futile.

The Borg, in other words, are a state of mind and a "bad idea" rather than a racial or perhaps even an ethnic identity. Seemingly paralleling anti-Communism in its most paranoid manifestations, the fear of the Borg is the fear of a dire fate to which death is decidedly preferable. "Better morgue than Borg" may not have quite the ring that "better dead than red" possessed, but a tempting assumption is that the creation of the Borg for the 1980s Star Trek: The Next Generation television series was in keeping with the longstanding employment of movie and television genres as metaphoric encounters with the Soviet Union. Captain JeanLuc Picard's machine-gunning of his former crew members who have been assimilated in Star Trek: First Contact (1996) to many veteran television watchers is undoubtedly reminiscent of Matt Dillon's weekly outdrawing of the villainous gunfighter in the long-running television series Gunsmoke, or Alan Ladd's similar defeat of Jack Palance in the movie Shane (1953). Sometimes an evil is such that mere refusal of cooperation is inadequate; only an exceptional employment of technological force and disciplined training along the lines of the Protestant work-ethic are sufficient to win the encounter.

However, the Soviets had already come and gone before the 20th century was even finished, and to date no reasonable threat of similar magnitude has appeared on the American horizon or is even easily imaginable. Yet the Borg are still a potent media image sufficient for a major recurring presence during several seasons of the Star Trek: Voyager television series, and for Mirzoeff to devote an extended reading of Star Trek: First Contact in his often-assigned textbook An Introduction to Visual Culture. I would like to argue that the reason the Borg continue to be a recognizable focus of dire threat is that the cyborg creations are, in fact, a modern manifestation of the very first distinct literary genre created in the Anglo-American New World - the captivity narrative. Rather than a metaphoric iteration of the Communist threat, the Borg instead represent the age-old American paranoia of being held in thrall by an Other who would drag Americans where they do not wish to be dragged. The Borg are thus a manifestation of the four-century-old captivity narrative that gained instant popularity in the early days of British North America. Before I undertake a close analysis of the Borg in the film Star Trek: First Contact, I should proffer a few comments about the general nature of captivity narratives, and the psychoanalytic theory that explains their longstanding popularity.

Originally intended by the American Puritans to be object lessons in religious rectitude and self-denial, the captivity narrative received its first and arguably most memorable treatment in the account of Mary Rowlandson of her weekslong experience as a prisoner of the Indians during King Philip's War in the late 17th century. For background on the captivity narrative in general and Mary Rowlandson and King Philip's War in particular, an excellent source continues 
to be Richard Slotkin's 1973 book Regeneration Through Violence, in which he defines the captivity narrative as "a vehicle for justifying philosophical and moral values which may have been extrinsic to the initial experience but which preoccupied the minds of the reading public" (1973: 20). That war kills, then, is not precisely the point, nor is the fact that hostages sometimes do not survive; that one must preserve his or her soul from corruption is another matter entirely. The captivity narrative, therefore, is by no means incompatible with mainstream Christian faith, which stipulates that the protection afforded the hapless pilgrim in the throes of malevolent forces, human or otherwise, does not necessarily take the form of physical survival, but always without fail affords spiritual continuance if the victim maintains faith. A few words from Mary Rowlandson are helpful in describing the precise advantages afforded by faith during captivity:

When the Lord had brought His people to [captivity as hostages], that they saw no help in anything but Himself; then He takes the quarrel into His own hand; and though they had made a pit, in their own imaginations, as deep as hell for the Christians that summer, yet the Lord hurled themselves into it.

Rowlandson's language may be archaic, but it should be pointed out that her 1682 book The Narrative of the Captivity and the Restoration of Mrs. Mary Rowlandson was an instant best-seller and was so popular both in British North America and England that it went through four editions in the first year (Derounian 1988: 239). Many readers during the last four centuries have taken inspiration or at least have discovered intellectual interest in the prototypical tale of the individual who was taken hostage and forced not only to seek out new reservoirs of resourcefulness, but also to maintain rigid devotion to a way of life that contrasted to that which the captors were attempting to impose. The captivity narrative provided a secular addendum and philosophical justification to the 2,000-year-old Biblical stories that colonialists were always eager to consume. Even if the early settlers had little idea of precisely how they intended to manifest the "city on a hill" that John Winthrop memorably coined on the way to the place that would come to be known as Boston, they did know that being captured body and soul by the swarthy people of the forest was definitely not part of the program. As I have argued in a previous paper, the Native Americans were not so much the focus of danger as they were a plot device aimed at providing a gripping narrative of how one should acquire the proper amount of Christian faith and devotion (Tindol 2009).

Because the Anglo-American settlement of the New World was predicated on freedom from various forms of thralldom, including that at the hands of the Native Americans who preceded their arrival, the captivity narrative provided a dramatic acting-out of the freedom-seeking that supplemented standard Biblical exegesis. As Peter Brooks has pointed out in his standard work Reading for the Plot, "narrative...is hermeneutic in intention, claiming to retrace event in order to make it available to consciousness" (1984: 34). And not only did narrative sup- 
plement exegesis in the early days of British North America; the telling of those stories also provided entertainment.

The popularity and success of the captivity narrative is not surprising in a colony that was willing to forgo the comforts and security of the known to seek the promise of an ambivalent and ill-defined "freedom" that seemingly implied an eternal "freedom-from" rather than a "freedom-to." As Brooks also writes, the circuitous nature of many narrative stories can obviate more positive resolutions:

The deviance and error of plot may necessarily result from the interplay of desire in its history with the narrative insistence on explanatory form: the desire to wrest beginnings and ends from the uninterrupted flow of middles, from temporality itself; the search for that significant closure that would illuminate the sense of an existence, the meaning of life. (Brooks 1984: 140)

To extrapolate, the early settlers of British North America have in common with their $21^{\text {st }}$-century descendants the need for playing out the New World experience as a romantic quest for an elusive "freedom-from." Today as four centuries ago, we all possess a seemingly bottomless appetite for repeated tellings of the narrative of those who have dramatically fought for their freedom from the Other.

How enticing is this line of narrative? Peter Brooks's book is heavily steeped in Freudian psychoanalysis, and modern theory is especially relevant in illuminating the narrative power of the tricky dance of religious devotion with the "freedom-from." Jacques Lacan's mirror stage, in particular, explains how our very early and traumatic experiences in learning to discriminate between our individual selves and the external world can apply to the way we feel about various aspects of that external world. Though Lacan's famous essay "The Mirror Stage" does not touch on the captivity narrative, it nonetheless resonates with the story of the flight from the threatening Other:

But the important point is that [the Ideal-I] situates the agency of the ego, before its social determination, in a fictional direction, which will always remain irreducible for the individual alone, or rather, which will only rejoin the coming-into-being (le devenir) of the subject asymptotically, whatever the success of the dialectical syntheses by which he must resolve as I his discordance with his own reality. (Lacan 2001: 2)

The captivity narrative can therefore be taken as an exemplar of the personal creation of the ego that actually predates the religious homilies that were so much a part of the typical Puritan's early Christian upbringing. In short, the captivity narrative is earlier in our awakening individual consciousnesses and even more visceral than the enjoinder to do good and maintain one's Christian faith. Small wonder that the literary genre continues to have traction in the semi-utopian world of $24^{\text {th }}$-century Star Trek. 
The relevance of $24^{\text {th }}$-century quality of life is by no means a cursory statement, because the entire argument of Star Trek: First Contact is that life on Earth has become near-utopian because the Borg were never permitted a toehold on the planet. The movie concerns a travel to mid- $21^{\text {st }}$-century America after the Picard crew of the Enterprise has won a skirmish with the Borg some 300 years in the future. Unable to conquer the Federation in a direct battle, the Borg have elected to go back in time and prevent the very history that provided Earth with its puissance and its resistance to outside influence - namely, the original contact with the Vulcans that first notified Earthlings that they were not alone in the universe. This is the "first contact" of the film's title, and if we willingly suspend our disbelief, this first encounter in the Star Trek universe somehow liberalizes humanity to the extent that war on Earth is virtually eliminated and disease and various social ills are marginalized almost out of existence.

Thus, the $24^{\text {th }}$-century Earthlings of the normal time-line prefer for things to remain the way they are, and certainly do not wish to fall victim to the Borg, who originate from the far end of the Milky Way galaxy and turn every other humanoid they encounter into Borg automatons. If one is "infected" during a rather traumatic physical encounter involving some sort of nanotechnological implants and removal of arms and left eyeballs for the fitting of robotic devices, then one loses all individual identity and becomes a telepathically-linked drone within the Borg collective until his or her life functions terminate.

Picard is the focus of the story, as always, in the various television and cinematic Next Generation iterations, but this time is also the narrator of the captivity story in much the same manner as Mary Rowlandson. This is because he has previously been a Borg drone (in a television episode titled "The Best of Both Worlds"), and knows first-hand how justifiable is his crew's fear of Borg infestation, and how visceral should be their endeavors to terminate all Borg presence in the universe with extreme prejudice. Everyone else in the Federation fleet is presumably of the same opinion, for Commander Worf in a separate Federation starship in dire peril of destruction says "perhaps today is a good day to die. Prepare for ramming speed"1 just before the Enterprise appears and destroys the Borg starship threatening his own. Even though Worf is an ascetic Klingon who is perpetually ready to die bravely and unflinchingly in battle, virtually every other human in the Federation fleet seems to have precisely the same attitude toward the Borg threat. If anyone among the human fleet thinks that there is any alternative to Borg assimilation other than suicide as a last resort, they certainly do not voice their opinion.

Nor does anyone seemingly object when Picard tells the crew to kill without hesitation all former crew members who have been transformed into Borg drones. When the Enterprise crew later discover that their starship has been infiltrated and partially taken over by Borg, Picard's orders are to open fire even if the Borg is a former colleague or friend. "Believe me, you'll be doing them a favor," Picard says, making good on his words a few minutes later when a crewmember named Lynch shows clear signs of nanoinfestation and reaches out, saying "help 
...please help!" Picard kills him with a phaser blast. Precisely why the death of all Borg is preferable to their possible rehabilitation goes unexplained, for if Picard's crew had taken his current advice, he would no longer be alive to command a Starship fleet.

Meanwhile, the android Data, another venerable crew-member from previous Next Generation iterations, has been captured and incapacitated by the Borg. Unlike the humans, he cannot be assimilated, but with the appearance of the Borg Queen it is soon revealed that he can be persuaded to take the Borg side if he so desires. And to raise the ante, the Borg provide the android with human skin implants in order to augment his sexual response. For all we know, Data is indeed enticed to join the Borg so that he can enjoy at least a half-human existence in the future.

Picard, meanwhile, is working to defeat the Borg on the Enterprise by employing the knowledge he gained of them during the brief time he was assimilated. After the machine-gunning of a couple of his former crew members, he works on a weapon that will overcome the Borg infiltrators, even though all other humans on board have decided by this point that the best thing to do is blow up the ship and escape to the mid- $21^{\text {st }}$-century Earth below, even though they will be stranded permanently on an Earth 300 years before they are even born. Picard counters that his headstrong actions are not due to his thirst for revenge, but rather are aimed at "saving the future of humanity." Denying that he is merely a Captain Ahab out to avenge a previous wrong, Picard eventually relents and sends the entire human crew of the Enterprise to Earth, but remains on board in a seemingly suicidal mission. He tells one of his new $21^{\text {st }}$-century allies that he is doing so to save Data.

Quickly finding the Borg Queen and the now seemingly compliant Data, Picard offers to exchange his own willing assimilation if the Borg will let Data go. For a moment, Data apparently cooperates with the Borg, even pretending to shoot a photon torpedo toward the primitive $21^{\text {st }}$-century spaceship that has now been launched from the planet's surface in order to be detected by the Vulcans and bring forth centuries of Earthly peace and prosperity. But Data has been pretending to ally himself with the Borg, and quickly turns the tables, allowing Picard to destroy the "human" flesh of all the Borg by rupturing a tank of highly corrosive coolant. Picard remains above the coolant, but the Borg are all killed, their life functions depending on the presence of a certain amount of organic material. Data's recently-acquired sensual human flesh is also destroyed, leaving his internal machine parts exposed, but he then admits that he was tempted for "precisely zero point eight seconds" because the Borg Queen had "brought me closer to humanity than I could have thought possible."

The Borg threat at least temporarily finished, the Enterprise crew then beam to the surface of Earth (to Montana, more precisely) to savor the first contact between humans and extraterrestrial Vulcans before the credits roll.

In sum, Star Trek: First Contact is relentless in discounting any possible benefit that could come from an encounter with an alien form such as the Borg. The only 
viable response to the Borg in the Star Trek universe is an all-out and unyielding effort to destroy not only every Borg drone, but every link to and manifestation of the Borg universe. The only good Borg is a dead Borg, one must assume, which is a surprising contradiction considering that Star Trek is a science-fiction franchise that has been lauded for decades for its humanity and tolerance. Donna Haraway may have a perfectly valid point in her classic essay in "making an argument for the cyborg as a fiction mapping our social and bodily reality and as an imaginative resource suggesting some very fruitful couplings" (1991: 150). But in the Star Trek universe, such couplings are a non-starter.

The point is not that the series makers should consider a few episodes or even a movie script in which the Borg state is reluctantly accepted by a character as a not-so-terrible alternative, but rather that the Borg provides a metaphorical enemy in which an all-out battle can be fought without the least compulsion of allowing quarter to the enemy or prisoners to be taken. As such, the Borg threat is reminiscent of the captivity narrative in its all-encompassing aversion to any sort of contact with the dreaded Other. One can maintain individual identity only by rejecting wholesale the corrupting influence of the would-be captor, and any sort of acquiescence is the certainty of doom. In the Star Trek mythos, then, the Borg represent a surprisingly conservative return to a fear of the Other than was a feature of American creative works long before Hawthorne's Goodman Brown agonized over the potential for an Indian behind every tree.

\section{Notes}

1 “Star Trek: First Contact.” chakoteya.net. Chrissie’s Transcripts Site, n.d. Web. 6 Jan. 2012. All direct quotations from the film are from this transcription.

\section{References}

Brooks, Peter (1984) Reading for the Plot. Cambridge: Harvard University Press.

Derounian, Kathryn Zabelle (1988) 'The Publication, Promotion, and Distribution of Mary Rowlandson's Indian Captivity Narrative in the Seventeenth Century.' Early American Literature 23 (3), 239-261.

Haraway, Donna (1991) 'A Cyborg Manifesto: Science, Technology, and Socialist-Feminism in the Late Twentieth Century.' In: Simians, Cyborgs and Women: The Reinvention of Nature. New York: Routledge, 149-181.

Lacan, Jacques (2001) 'The Mirror Stage as Formative of the Function of the $I$ as Revealed in Psychoanalytic Experience.' In: Ecrits: A Selection. London: Routledge, 1-8.

Mirzoeff, Nicholas (1999) 'First Contact: From Independence Day to 1492 and Millennium.' In: Mirzoeff, Nicholas (ed.) An Introduction to Visual Culture. London: Routledge, 193-227.

Rowlandson, Mary (1682) The Narrative of the Captivity and the Restoration of Mrs. Mary Rowlandson. < http://www.library.csi.cuny.edu/dept/history/lavender/rownarr.html > Accessed on: 22 May, 2008.

Slotkin, Richard (1973) Regeneration Through Violence: The Mythology of the American Frontier 1600-1860. Middletown: Wesleyan. 
"Star Trek: First Contact." chakoteya.net. Chrissie's Transcripts Site, n.d. Web. 13 Nov. 2011.

Star Trek: First Contact. Dir. Jonathan Frakes. Paramount, 1996. Film.

"The Best of Both Worlds Part 1-2." Star Trek: The Next Generation. Paramount Television. 18 June 1990 and 24 Sept. 1990.

Tindol, Robert (2009) 'Tom Sawyer and Becky Thatcher in the Cave: An Anti-Captivity Narrative?' The Mark Twain Annual 7 (1), 118-126.

ROBERT TINDOL is a visiting faculty member in the Division of English Language and Culture at the Guangdong University of Foreign Studies in Guangzhou, China. He teaches graduate courses in literature, critical theory, and cultural theory, as well as various undergraduate courses. A native of Texas and a former science journalist, he is a specialist in early-American and nineteenth-century American literature, and has published articles on Cotton Mather, Henry David Thoreau, Mark Twain, and Henry Adams. He earned his Ph.D. in literature at Claremont Graduate University in California.

Address: Dr. Robert Tindol, No. 5309 Foreign Faculty Building, Guangdong University of Foreign Studies, Guangzhou, China 510420. [email: roberttindol@hotmail.com] 